\title{
Construction on Practical Teaching System for Marketing Specialty
}

\author{
Shijie Zhang \\ College of Finance and Trade, Bohai University, Jinzhou, 121013, China
}

2824834538@qq.com

Keywords: marketing specialty; practical teaching system; construction principles; practical teaching strategies

\begin{abstract}
Practical teaching is an effective way to consolidate theoretical knowledge and deepen theoretical understanding. In view of the current practice teaching of marketing specialty in schools and teachers is not paying enough attention, the professional teachers generally lack the practical experience and the lack of systematic teaching practice. This paper based on constructivism theory, multiple intelligences theory and situational learning theory as a guide, follow the integrity, practical, standardized and orderly, comprehensive and forward-looking principle, to build a marketing professional practice teaching system, and put forward the marketing specialty to carry out practical teaching strategies. The research results of this paper make the practice teaching more theoretical and systematic, and the practice teaching idea is clearer, which can help to cultivate the high quality marketing talent.
\end{abstract}

\section{Introduction}

The marketing specialty is to cultivate the moral, intellectual and physical development of the socialist market economy. It understands the market economy, has a solid foundation and wide knowledge. It not only understands the marketing practice and management, but also is familiar with the national economic and trade policies and decrees. And can skilled use of computer, understand the import and export business, familiar with foreign trade knowledge, master of business management knowledge and marketing skills, strong practical ability and practical talents. Practical teaching is an important way to consolidate theoretical knowledge and deepen the understanding of theory. It is an important link to cultivate high-quality engineering and technical personnel with innovative consciousness. It is an important platform for theory to practice and cultivate students to master scientific methods and improve hands-on ability. Through the practice of teaching, enrich and active students' scientific thinking, to deepen the understanding of theoretical knowledge, to cultivate students that to observe the objective world and analytical ability, to understand the status and role of practice in the development of scientific theory. Marketing graduates generally cannot meet the needs of the market, strengthen the practice of teaching is an effective way to solve this problem.

Carrying out practice teaching has its profound theoretical basis. First, constructivist theory emphasizes the actual teaching activities and situational teaching content. Students are not only the main body of cognitive activities, but also an indispensable part of social activities, only in real life and practical activities is conducive to the completion of cognitive activities. Therefore, to construct the practical teaching system, we should use situational teaching methods to make students conduct cognitive activities more deeply in order to effectively master the knowledge and skills they have learned. Second, the theory of multiple intelligences emphasizes the cultivation of practical ability in life and work. The ultimate goal of learning knowledge is to serve the production, and the ultimate goal of the theory is to practice. Therefore, we should enhance students' practical ability. The purpose of education is to cultivate people with intellectual, professional and practical skills, and professional knowledge is the prerequisite for production practice. Therefore, in the process of education, should combine the specific characteristics of students, flexible guidance, to achieve the comprehensive progress of intelligence and practice. Third, situational learning theory emphasizes the practice activities of participation community. Learning is not just the construction of individual meaning, but also has social and practical. Through situational play and contextual interaction, 
learners can recognize themselves, accumulate experience and master new knowledge. By setting specific goals and programs to stimulate students' ability to think independently, encourage mutual cooperation among students, develop team awareness and improve comprehensive ability.

Due to the lack of scientific guidance on practical teaching, practical teaching is blind and cannot meet the requirements of pre-service education development. Based on the basic theory, this paper constructs the practice teaching system of marketing specialty and puts forward the practice teaching strategy so that the practice teaching is more theoretical and systematic, and the practice teaching idea is clearer and helps to cultivate the high quality marketing talent.

\section{Construction Principles}

To build a practical teaching system, to distinguish between other levels and categories of education, in order to improve students' ability to adapt to the workplace as the goal, the comprehensive utilization of various factors, to fully mobilize all aspects of enthusiasm. The following principles should be followed in the construction process:

(1) The principle of integrity. Practical teaching system is an organic system, in this system, the various elements interact, coordinate with each other and make overall plans, in order to make the practice of teaching to achieve the optimized function. The practical teaching system is composed of teaching objectives, teaching methods, teaching contents, training bases, teachers and students. Only by optimizing and perfecting these elements can provide a good learning environment for students. At the same time, we must take into account the unity of theoretical teaching and practical teaching, practical teaching content from easy to difficult, practical teaching methods from single to comprehensive.

(2) Practical principles. Practice is mainly reflected in the practice of curriculum, practice teaching process, practical guidance teachers and training base and so on. Through the analysis of the needs of practical ability to determine the content of practical teaching, and in accordance with the teaching content to plan, organize, implement and evaluate teaching activities. Practice base includes the Intramural practice base and practice base outside the school, which is an important place for students to develop skills. The construction of practice bases should be as close as possible to the real working environment, create the atmosphere of professional work, and imitate the enterprise culture and the way of communication, so as to enhance the students' professional consciousness.

(3) The principle of normative order. The horizontal elements of the system are relatively stable and orderly, and the vertical hierarchy is dynamic and orderly. The internal and external environment of the system is ordered and orderly, which is the inevitable result of the system to stabilize and keep the dynamic equilibrium. In the process of cultivating the program, we should standardize the time, content and form of the practice teaching, formulate the corresponding index system and assessment standard, and strive to achieve the norms and orderly between the departments and the upper and lower levels, so that have the funds guarantee, guarantee of time, personnel assurance and effectiveness assurance, to ensure the smooth operation of practical teaching.

(4) The principle of comprehensiveness. Comprehensiveness refers to the construction of practical teaching system must be better to meet the needs of students to learn. First, the function of the practical teaching system is comprehensive. To meet the needs of the development of social diversification, will cultivate students' professional ability in a prominent position, and at the same time, taking into account the formation of professional quality of students, including good professional ethics, team spirit, dedication, quality awareness and innovation awareness. Second, the content of the practical teaching system is comprehensive. Mainly including the target system, design system, resource system, management and evaluation system, each sub-system is an indispensable part of the practice teaching system.

(5) Forward-looking principles. With the development of science and technology and the renewal of scientific achievements, the social changes in the demand for different talents are accelerating. The talents cultivated by higher education should meet the needs of social 
development, and the curriculum content, teaching methods and training programs of practical teaching must be constantly updated. Cultivated students have a sense of advance, able to moderate the needs of future social development. Schools should strengthen their close cooperation with the enterprise, closely follow the pace of production technology update, improve the professional settings, replace the professional course content, and hire senior management personnel of enterprise, the use of the latest technology to carry out practical teaching.

\section{Practical Teaching System}

The general practice teaching system should include target system, content system, implement approach system, management system, and guarantee system and feedback system. The target system plays a guiding and driving role in practice teaching system, construction should fully embody the education concept and marketing concept, fully embodies the require (students, family and social needs) to train suitable talents management thoughts; on the basis of the school and professional orientation, combined with social evaluation and school self evaluation results, considering the requirements and characteristics of marketing professionals training objectives, to determine the specific content. The content system is the core system of the practical teaching system, is the teaching content of the practice teaching (experiment, practice, training, curriculum design, graduation design, scientific research training and social practice) through reasonable configuration, involved in all aspects of the cultivation of students' ability. The implement means system refers to the practice teaching approach and the concrete practice content. The management system is an important part of practice teaching system, guidance and regulation in the whole system, mainly includes the management of the practice teaching management object, that is, the macro management of the school, the management of the students and the effective management of the teachers. The guarantee system only refers to the school's resources, equipment management, learning environment and logistics services. It is a prerequisite for practical teaching activities. Evaluation and feedback system refers to Social evaluation of students' practical activities, teachers' evaluation of students' practical activities, experts' evaluation of practical activities, and students' evaluation of practical teaching; evaluation and feedback system is to adjust and improve the practice teaching system, is the key to the formation of a new round of healthy operation.

In view of the characteristics of marketing teaching practice, this paper constructs a practical teaching system composed of practice type, practice session, practice goal and training goal, as shown in Fig .1.

\section{Practical Teaching Strategies}

The practical teaching system is a complete system framework that requires the joint efforts of the state, society, business, school and student. Need to be under the guidance of a certain strategy to really play a role. The strategy presented in this paper is as follows:

(1) The establishment of practical teaching management system and evaluation system. Through the system constraints, in the teaching practice, to conduct a rigorous assessment for instructors and students, students who fail their assessment will not be able to graduate normally. It is recommended that the graduation thesis of the marketing professional students be based on the experience of the enterprise practice, the holiday practice or the participation in the science and technology innovation skill competition, emphasizing the practical guidance and application value of the paper to evaluate the grade. The management of imperfect, demanding teachers and relevant supervisors, to be held accountable, and the work into the annual assessment and title assessment up, so that reward and punishment is clear, improve school leaders and teachers to attach importance to practice teaching, and practical teaching really play the role in the cultivation of students' ability.

(2) To build a diversified practice teaching base. Practice teaching base is the necessary condition to carry out practical teaching, the establishment of long-term stable practice teaching base is an important guarantee to strengthen the practice teaching link. Try to build a diversified practice base to meet the various needs of professional skills. First, the practice base in the school, 
mainly to verify the practice teaching, to promote the understanding of theoretical knowledge, is also a supplement and extension of theoretical teaching. Second, schools and enterprises to build a practical base, enterprises to provide the necessary resources, equipment and teachers, teachers and students to help enterprises to complete marketing work, which is a school and business win-win teaching model for It is also a supplement and extension of theoretical teaching. Third, the virtual practice base, the use of modern information technology, instead of expensive experimental equipment, students can repeatedly operate, experience the fun of work, and cultivate professional quality.

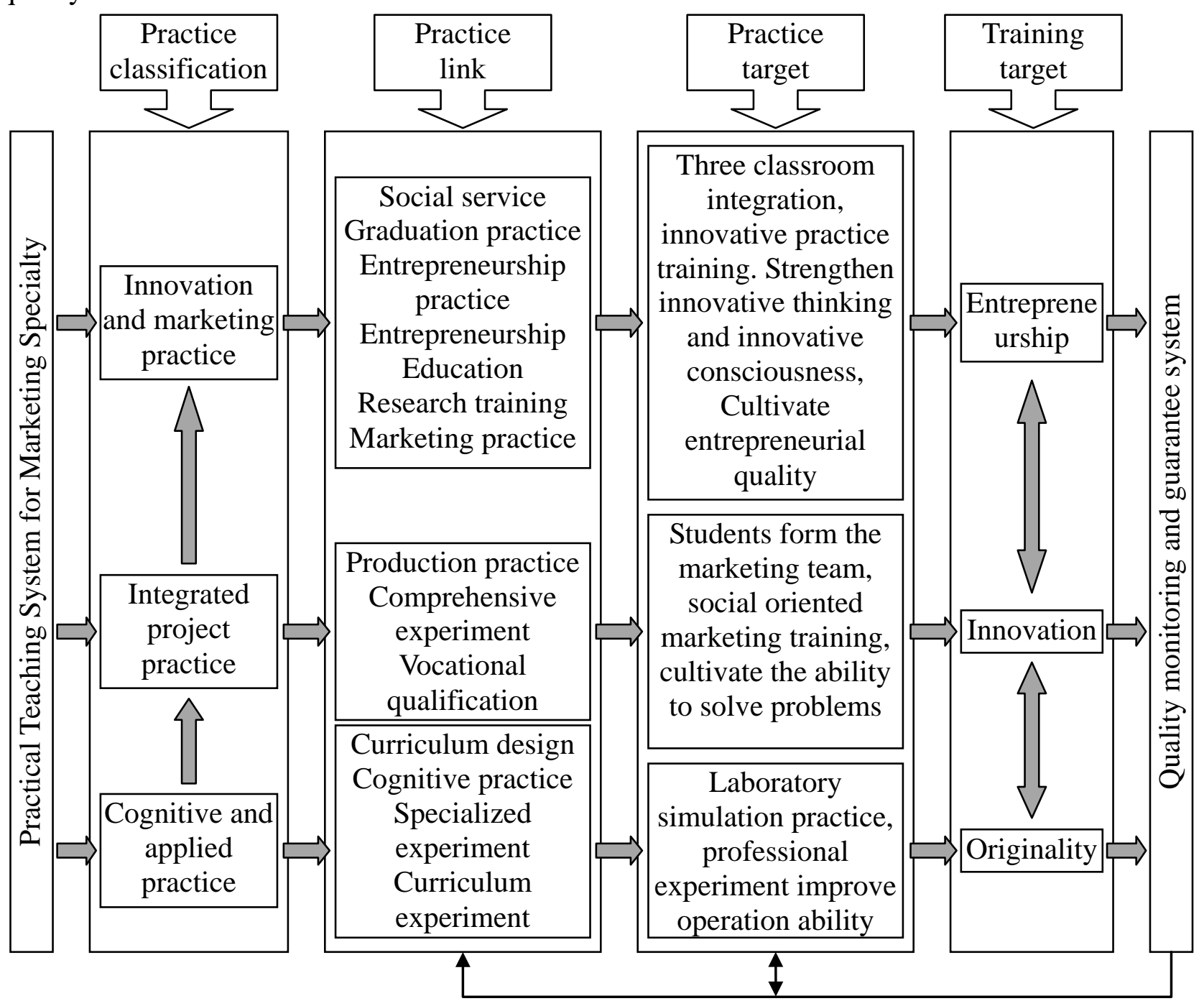

Fig. 1. Practical Teaching System for Marketing Specialty

(3) Popularize the use of project teaching method. Project teaching method is a kind of teaching practice carried out by teachers and students through the completion of a complete project. The specific approach is: the teacher contact the cooperation unit, signed the project cooperation contract; the students are divided into several groups, respectively, engaged in the work, clear roles and functions of each person in the group; the students in the learning of professional courses at the same time, the collection of relevant information and market survey; to develop project plans and cooperation with enterprises in the actual operation of the project; enterprises responsible for scoring and the application of programs, and put forward the new problem in the using of the project, summarize the implementation of the project. The project teaching method can not only train the students' actual operation ability, but also can achieve the purpose of mutual benefit with the enterprise.

(4) To carry out professional cognitive practice teaching links. Organize students to use the winter vacation and summer vacation to carry out market research, commitment to product promotion business, as well as to the enterprise marketing practice, to enable students to fully 
understand a product or business, including product knowledge, business profiles, industry market environment, job responsibilities and business work norms and so on, highlighting the ability of students to identify products, market research ability, marketing ability, negotiation ability, interpersonal ability and social adaptability, require students to write practical cognitive reports, sum up lessons, through professional cognitive practice to improve marketing level. Graduates of the graduating class are arranged to practice in the company every year, so as to deepen the understanding of marketing expertise and enhance the competitiveness of employment.

(5) The use of a variety of practical teaching model. In order to enable students to better grasp the relevant knowledge and skills, need to use a variety of practical teaching mode. Among them, the practical training, the use of professional equipment or software, training in the simulated situation, master the basic professional skills and operational skills, is the most commonly used form of practical teaching. Social practice is a loose organization, various forms and unique teaching effect in practical teaching activities, mainly in social studies, social life experience, scientific and technological activities and public welfare labor and other forms, broaden the students' horizons, improve their own quality. Internship, in the real business environment, students uses the professional knowledge and skills to complete the task. Through practice, student is not only to enhance professional knowledge and skills, but also have a preparation to get into the real work. Graduation design is the last practice of students during the school period, social research and practical marketing activities are summarized as a specific document data, which provide theoretical guidance for future work.

\section{Conclusion}

The implementation of practical teaching mode of marketing specialty can comprehensively improve students' comprehensive quality and marketing ability, and form sound personality and firm will. Creative ability, communication ability, expression ability, leadership ability, market investigation and analysis ability, marketing planning ability and market development ability are comprehensively and systematically trained. It plays an important role in improving students' employability and adaptability in the workplace.

\section{References}

[1] L. Y. Feng, Y. Zhang, "Problems and Countermeasures in the practice teaching system of marketing practice in Colleges and Universities," Journal of Hubei University of Economics(Humanities and Social Sciences), vol. 12, no. 2, pp. 176-177, 2015.

[2] W. Shi, "On the university practice teaching system," Journal of Higher Education, vol. 34, no. 7, pp. 61-64, 2013.

[3] M. H. Zhou, T. Chang, "Construction and implementation of practical teaching model of marketing specialty," Heilongjiang Researches on Higher Education, vol. 25, no. 6, pp. 129-130, 2006.

[4] J. D. Hou, "Teaching System Construction of Simulation - Based Experiment for Marketing in the Higher Education," Journal of Hubei University of Education, vol. 33, no. 1, pp. 91-94, 2016.

[5] Y. S. Chang, "Probing on the Models of Practical Education of Marketing," Journal of Shanxi University of Finance and Economics(Higher Education Edition), vol. 9, no. 2, pp. 31-33, 2006.

[6] S. D. Zhao, Z. L. Pan, "Research on Practical Teaching System of Marketing Specialty in Application-oriented Colleges," Journal of Huangshan University, vol. 16, no. 2, pp. 109-112, 2014.

[7] J. Li, "Marketing in Higher Vocational Education: a new system of practical teaching," Vocational Education Research, vol. 30, no. 12, pp. 130-132, 2011. 